\title{
Accumulator Device
}

National Cancer Institute

\section{Source}

National Cancer Institute. Accumulator Device. NCI Thesaurus. Code C49806.

A device or material designed to collect a force or substance. 